\title{
Gastric Acid Secretion Inhibition
}

National Cancer Institute

\section{Source}

National Cancer Institute. Gastric Acid Secretion Inhibition. NCI Thesaurus. Code C41561.

Gastric Acid Secretion Inhibition involves interference with, or restraint of, hydrochloric acid release from gastric cells into the lumen of the stomach. Suppression decreases release of pepsinogen and inactivation of ingested microorganisms. 